\title{
PHF10 Gene
}

National Cancer Institute

\section{Source}

National Cancer Institute. PHF10 Gene. NCI Thesaurus. Code C157270.

This gene is involved in the proliferation of neural progenitor cells and chromatin remodeling. 